\title{
ANALISIS SEKATAN DAN KARAKTERISTIK SESAR PADA FORMASI KUJUNG REEF DI KOMPLEKS LAPANGAN KE, CEKUNGAN JAWA TIMUR: IMPLIKASI TERHADAP MIGRASI HIDROKARBON
}

\author{
SRI HARTANTO ${ }^{1,2}$, BENYAMIN SAPIIE ${ }^{2}$, INDRA GUNAWAN ${ }^{2}$, BINTORO WIBOWO ${ }^{1}$ \\ 1. PT. Pertamina Hulu Energi, Jl. T.B. Simatupang Kav 99, Jakarta 12520, Email: sri.hartanto@pertamina.com \\ 2. Program Studi Teknik Geologi, Fakultas Ilmu dan Teknologi Kebumian, Institut Teknologi Bandung (ITB), \\ Jl. Ganesha No.10, Bandung, Jawa Barat, Indonesia, 40132.
}

Sari - Pemodelan geologi bawah permukaan formasi Kujung Reef di area JS-1 ridge, saat ini hanya dikontrol oleh aspek stratigrafi dan penyederhanaan aspek struktur geologi dengan membuat seluruh sesar sebagai pembatas dari lapangan minyak dan gas. Penelitian ini dilakukan untuk mengetahui karakteristik sesar pada objektif Kujung Reef di area JS-1 ridge, dengan melakukan analisis pola dan daya sekat sesar untuk mengetahui pola penyebaran dan akumulasi hidrokarbon.

Analisis sekatan pada karbonat menggunakan metode Shale Gouge Ratio (SGR) (Yielding dkk., 1997) dihitung dengan dasar dua parameter utama yaitu throw sesar dan kandungan shale (vsh). Besar throw sesar didapat dari data seismik yang diikat dengan data sumur dan nilai vsh dihitung dari dua metode yaitu: single parameter (log Gamma Ray) dan dual parameter (log density dan neutron porosity) yang dikalibrasi dengan data multimineral. Hasil perhitungan menggunakan dua metode untuk vsh pada objektif memiliki pola yang serupa, dengan nilai vsh yang kecil yaitu 0-0.2, sehingga sesar-sesar pada area ini akan lebih di kontrol oleh juxtaposition antar reservoir dengan nilai SGR pada juxtaposition reservoir tidak lebih dari 16. Pada sesar yang berada pada area flank di sebelah tenggara JS-1 ridge berupa karbonat platform menghasilkan nilai SGR diatas 35, sehingga sesar ini menjadi penyekat yang baik.

Hasil akhir penelitian ini dapat menjawab pola migrasi hidrokarbon pada sesar di area JS-1 ridge berupa rekomendasi eksplorasi hidrokarbon, yaitu: 1) Area JS-1 ridge, hidrokarbon akan terakumulasi pada seluruh area tinggian di atas zona air regional, 2) Area barat laut JS-1 ridge, hidrokarbon akan terakumulasi pada reservoir yang lebih dangkal yang juxtapose dengan Kujung Reef dan 3) Area sebelah tenggara, hidrokarbon akan terakumulasi pada reservoir dibawah Kujung Reef yang berbatasan dengan sesar.

Kata kunci: sesar, throw, Kujung Reef, volume shale, juxtaposition, sekatan sesar, shale gouge ratio

\begin{abstract}
Subsurface geological modeling of the Kujung Reef formation at the JS-1 ridge is only controlled by stratigraphic aspect and simplification of structural aspects by using solely fault as boundary of oil and gas field. Objective of this research is to understand the fault characterization of the Kujung Reef Formation in the JS-1 ridge area, by analyzing the fault patterns and fault seals to define the migration pathway and accumulation of hydrocarbon.

Fault Seal Analysis in carbonate using shale gouge ratio (SGR) method (Yielding et al., 1997) that calculated based on two major parameters: fault throw and volume shale (vsh). Fault throw derived from seismic data that controlled by well data, while values of vsh were calculated by two different methods: single parameter (log Gamma Ray) and dual parameter (log density and log neutron porosity) with correction by multi mineral data. Results of vsh calculation using two methods objectively have similar pattern, with value around 0-0.2 "low vsh". It caused faults in reef dominated were more controlled by juxtaposition between reservoirs with SGR values of less than 16. Fault located in flank area that located at south east of the JS-1 ridge with dominant platform carbonate, has SGR value of more than 35 and made this fault as a good sealing.
\end{abstract}


The result of this research can be used to define the accumulation potential of hydrocarbon based on it's migration pattern, such as: 1) In JS-1 ridge area, the hydrocarbon will be accumulated on structure above of regional water zone, 2) to the northwest of JS-1 area, the hydrocarbon will be accumulated at younger reservoir that juxtapose with Kujung Reef, and 3) at the southeast area, the hydrocarbon will be accumulated at the reservoir below of Kujung Reef "non reefal" with fault bounded as a boundary.

Keywords: fault, throw, Kujung Reef, volume shale, juxtaposition, fault seal analysis, shale gouge ratio.

\section{PENDAHULUAN}

Kompleks Lapangan KE merupakan kumpulan beberapa lapangan minyak dan gas dengan bentuk struktur pinnacle yang banyak terpotong oleh sesar-sesar normal. Dengan adanya sesar yang berpotensi menjadi penyekat antar struktur, pemodelan daya sekat pada sesar sangat diperlukan untuk mengetahui kompartemenisasi dan akumulasi dari hidrokarbon untuk perhitungan cadangan sebagai dasar strategi pengembangan lapangan.

Secara geologi regional, Kompleks Lapangan KE berada pada JS-1 ridge yang merupakan bagian dari cekungan Jawa Timur, di batas tenggara dari kraton Sunda dan merupakan cekungan belakang busur berumur Tersier.
Menurut Satyana (2005) JS-1 ridge berada pada mandala northern platform dengan struktur yang telah terjadi pada pre tersier (suture meratus) dan selama Eocene Miocene berkembang dengan tebal terumbu yang kemudian pada Plio-Plistocene tereaktifasi akibat pergerakan Lempeng Australia terhadap Lempeng Eurasia (Gambar 1).

Kuantifikasi daya sekat sesar pada saat ini lebih banyak diaplikasikan pada batuan siliciclastic, maka analisis daya sekat pada Kujung Reef akan diawali dengan melakukan validasi terhadap properties yang didapat dari data sumur.
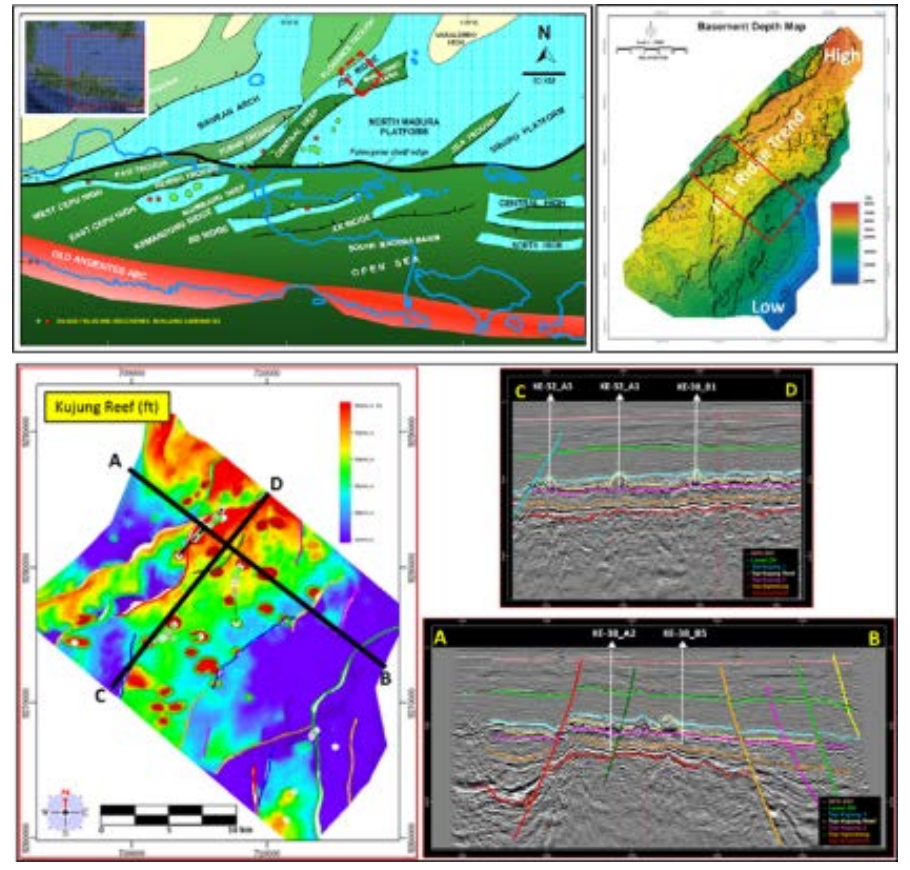

Gambar 1. Geologi Regional Cekungan Jawa Timur beserta area penelitian. 


\section{DATA DAN METODOLOGI}

\subsection{Data}

Data yang digunakan dalam penelitian ini meliputi (Gambar 2):

a) Data seismic 3D PSDM dalam format kedalaman kaki ( $f t)$.

b) Beberapa data sumur eksplorasi dan pengembangan berupa kurva log gamma ray (GR), log densitas (RHOB), log neutron (NPHI) dan batas kontak hidrokarbon.

\subsection{Metodologi}

\subsubsection{Penentuan Tipe dan Jenis Sesar}

Penelitian diawali dengan mengetahui proses terjadinya sesar berdasarkan kedalaman beserta arah pergerakannya. Menurut Sibson (1977) proses terjadinya sesar pada kedalaman 1-4 km menghasilkan incohesive cataclasites dan menurut bahan material kursus Traptester oleh Badleys tahun 2004 detail incohesive cataclasites tersebut akan menghasilkan jenis sesar yang berbeda berupa breccia, gouge hingga shale smear Gambar 3).

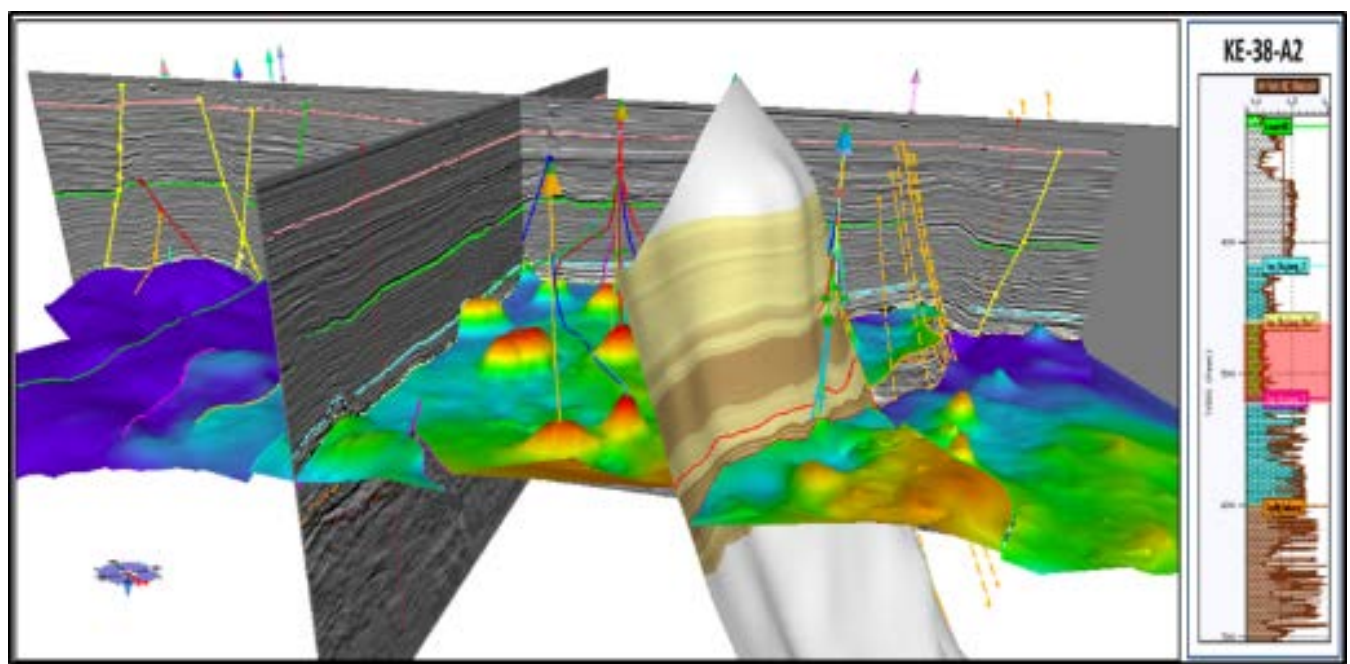

Gambar 2. Kelengkapan data subsurface yang digunakan untuk analisis daya sekat sesar.

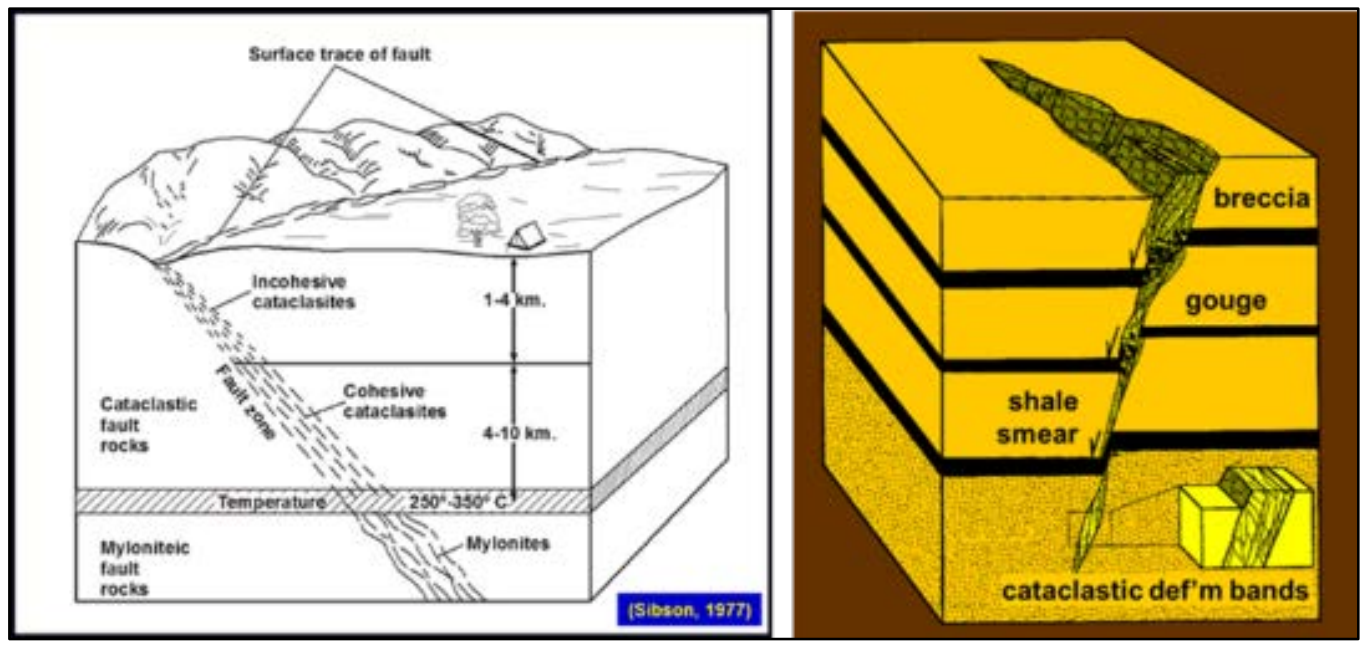

Gambar 3. Variasi jenis sesar terhadap kedalaman (Sibson, 1977). 


\subsubsection{Penentuan Komposisi Litologi}

Setelah mengetahui jenis sesar berdasarkan proses kejadian, tahap selanjutnya adalah menentukan komposisi litologi akibat gerusan pergerakan sesar. Menurut Yielding (2002), salah satu faktor penentu komposisi pada bidang sesar adalah banyaknya kandungan komposisi batulempung terhadap kedalaman (burial) pada saat sesar terbentuk. Pada penelitian daya sekat sesar dengan objektif reservoir terumbu (Kujung reef) dengan kandungan clay yang rendah dan kedalaman sekitar 1000-2500 meter menghasilkan produk sesar yang akan terbentuk antara disaggregation zones atau shale gouge (Gambar 4).

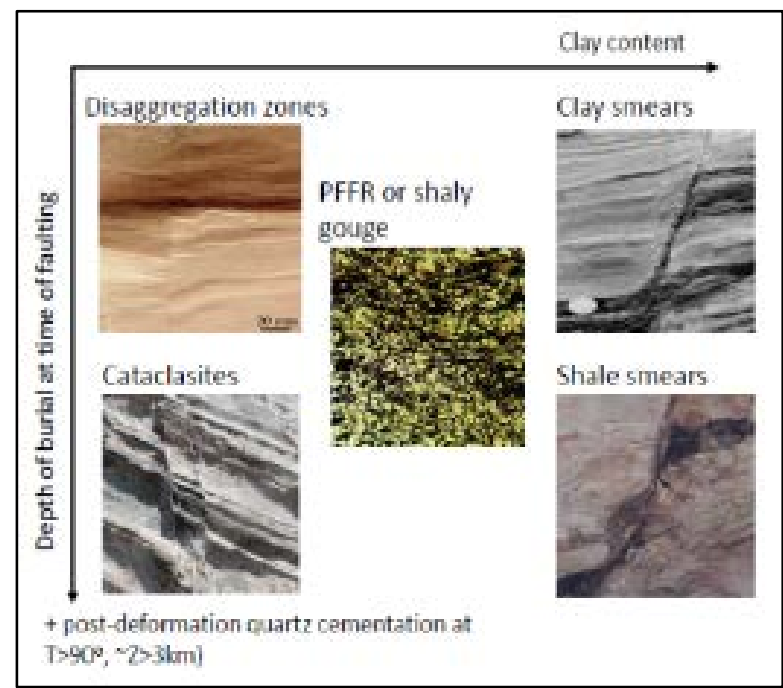

Gambar 4. Tipe batuan pada bidang sesar berdasarkan kandungan dan kedalaman terjadinya sesar (Yielding, 2002).

Pemodelan yang dilakukan secara kuantitatif pada umumnya menggunakan metode Yielding (1997) dengan objek reservoir batupasir seperti terlihat pada Gambar 5 . Dasar dari metode ini adalah penelitian yang dilakukan pada singkapan permukaan (Gambar 5 tengah) dengan melakukan analisis pada litologi batuan samping dan litologi batuan produk sesar. Metode analisis ini telah dilakukan juga pada data bawah permukaan dengan menganalisis batuan inti yang terdapat bidang sesar (Gambar 5 kiri). Hasil dari penelitian tersebut didapatkan bahwa produk sesar adalah kumpulan dari mineral halus (clay) dari batuan samping yang tergerus oleh sesar. Persamaan untuk mengetahui karakterisasi dan implikasi dari produk sesar ini biasa disebut metode shale gouge ratio (Gambar 5 kanan).

Karena pada penelitian, litologi yang diamati adalah batuan karbonat terumbu, metode yang digunakan adalah shale gouge ratio. Kandungan shale didapat dari data logging yang hasilnya di kalibrasi dengan sayatan tipis dari batuan inti.

\subsubsection{Pembuatan Model Sesar}

Pengaplikasian untuk penelitian daya sekat sesar pada data bawah permukaan, diawali dengan melakukan analisis seluruh data sumur berupa data logging yang sudah dikoreksi dengan data batuan inti dan sejenisnya (Gambar 6). Kemudian data tersebut diikat dengan data seismik untuk mengetahui penyebaran dari litologi hasil interpretasi data sumur. Selain itu, pada data sumur dilakukan identifikasi kondisi struktur sesar yang diamati (Gambar 6 kiri dan tengah). Salah satu hasil dari interpretasi seismik adalah geometri bidang sesar yang kemudian pada bidang sesar tersebut akan di sebarkan data dari sumur untuk mengetahui penyebaran stratigrafi, peta Allan (juxtaposition) dan besar throw sesar (Gambar 6 di kanan). 


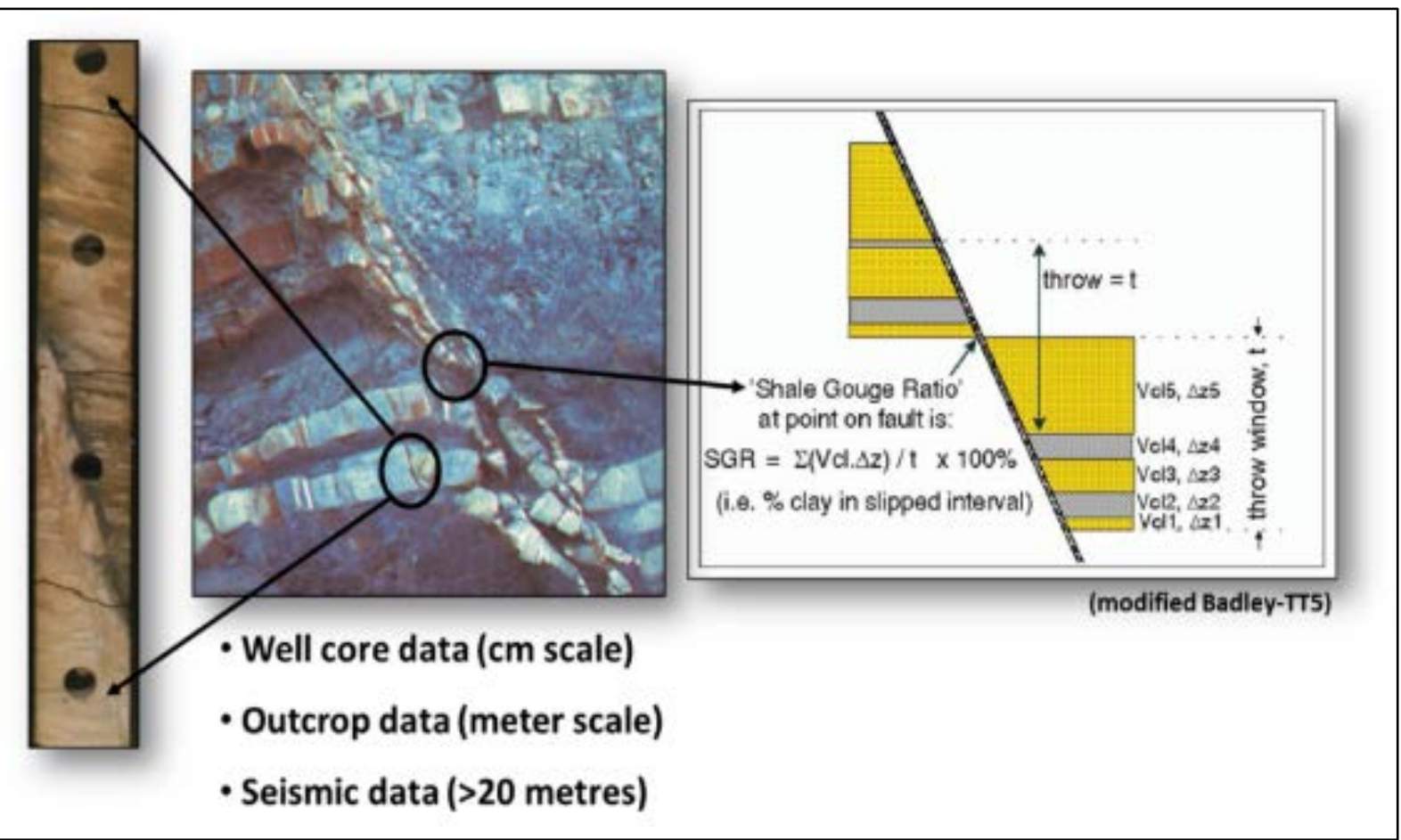

Gambar 5. Metode memprediksi komposisi pada bidang sesar (TT5 course, 2004).

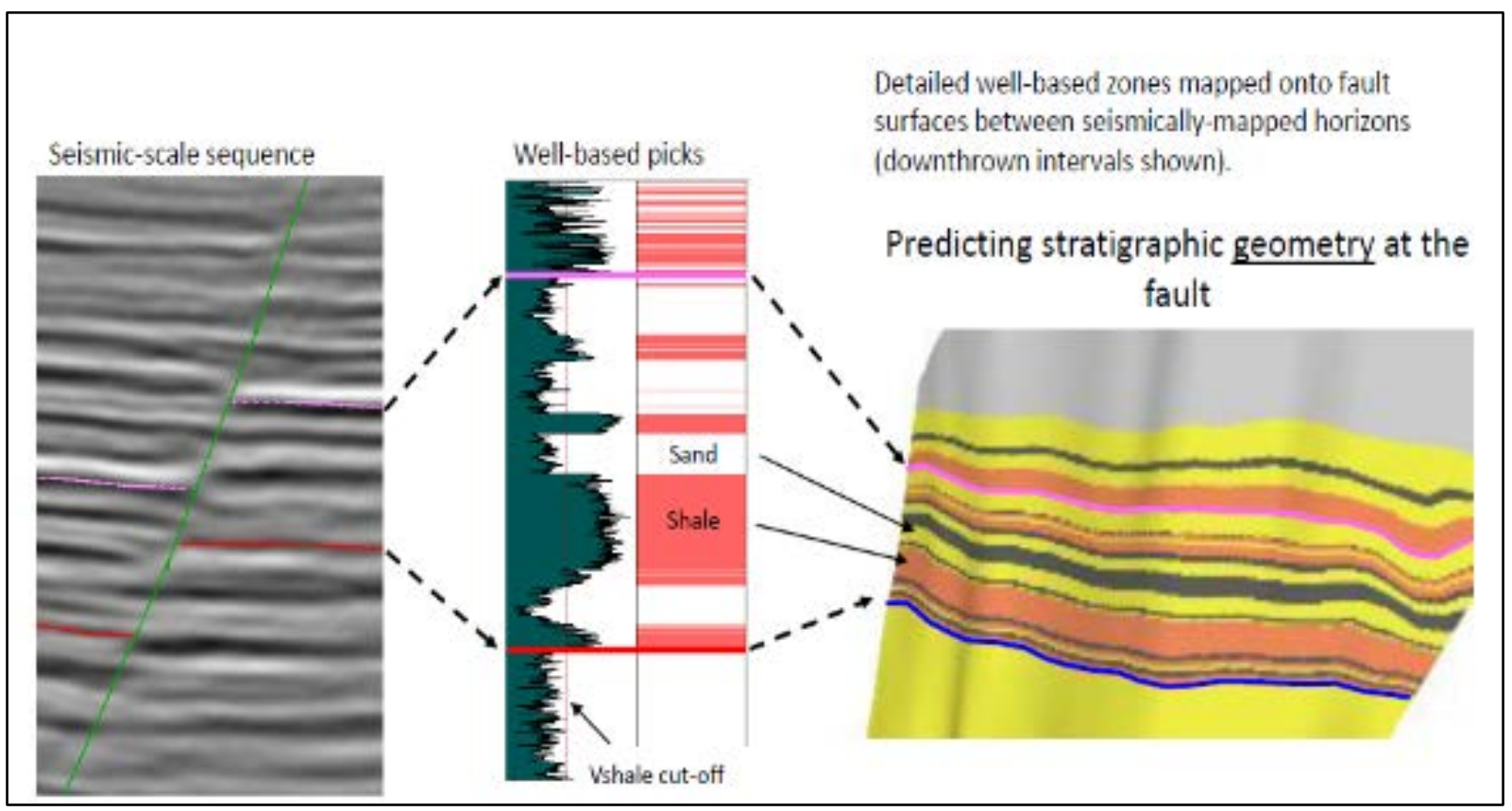

Gambar 6. Data yang dibutuhkan dalam pemodelan daya sekat pada bidang sesar (TT Course, 2014). 


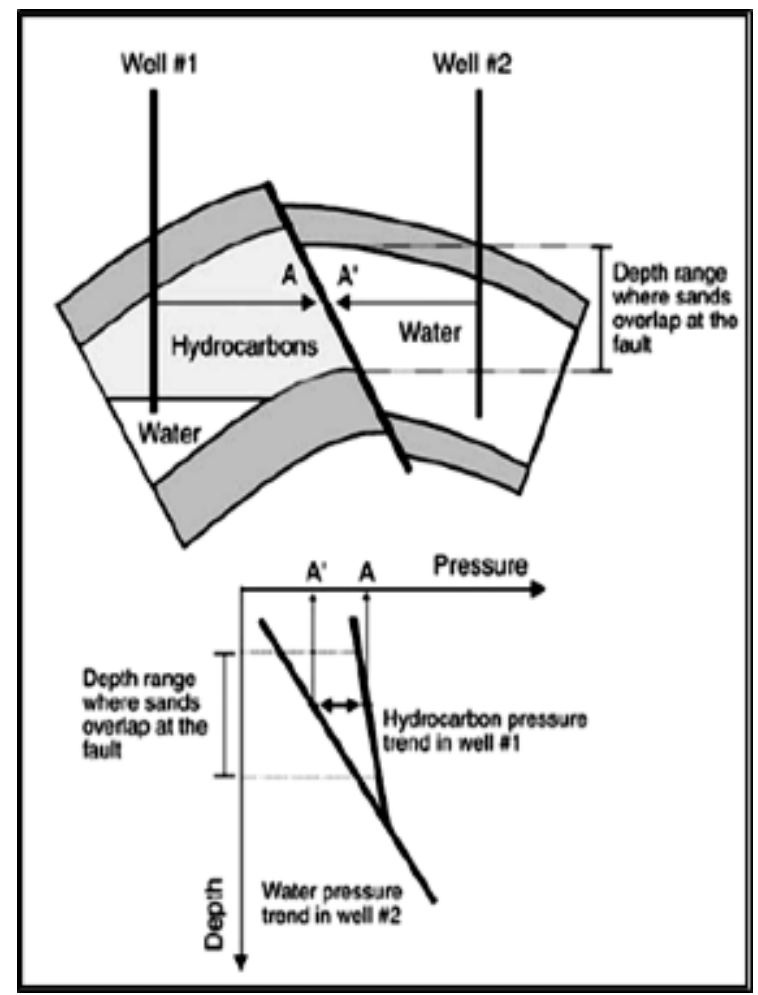

Gambar 7. Kalibrasi dari analisis sekatan pada sesar dengan cara membandingkan perbedaan kedalaman kontak fluida dan beda tekanan sumur (Yielding dkk., 2010).

\subsubsection{Kalibrasi}

Tahap keempat adalah pembuktian/kalibrasi dari analisis yang sudah di-hasilkan dengan cara melakukan korelasi tekanan pada data uji sumur dan data kontak fluida yang ada di sumur pada kedua sisi dari bidang sesar yang sudah di analisis (Gambar 7) (Yielding dkk., 2010).

\section{HASIL}

\subsubsection{Perhitungan Volume Clay}

Berdasarkan perbandingan perhitungan volume clay dengan dua metode yang akan dijadikan sebagai vsh pada penggunaan metode SGR, didapatkan besar nilai volume shale pada batugamping tidak menghasilkan perbedaan yang signifikan. Berdasarkan sayatan tipis dan karakter terumbu dari data sumur didapatkan penerapan GR (single parameter) akan lebih mendekati pada litologi terumbu dengan kondisi clay yang bersih pada sumur U-A2 (Gambar 9) dan U-A11st (Gambar 10) dan untuk dual parameter (density dan neutron) akan lebih mendekati pada litologi yang memiliki perselingan clay nya (U-A1) (Gambar 8).
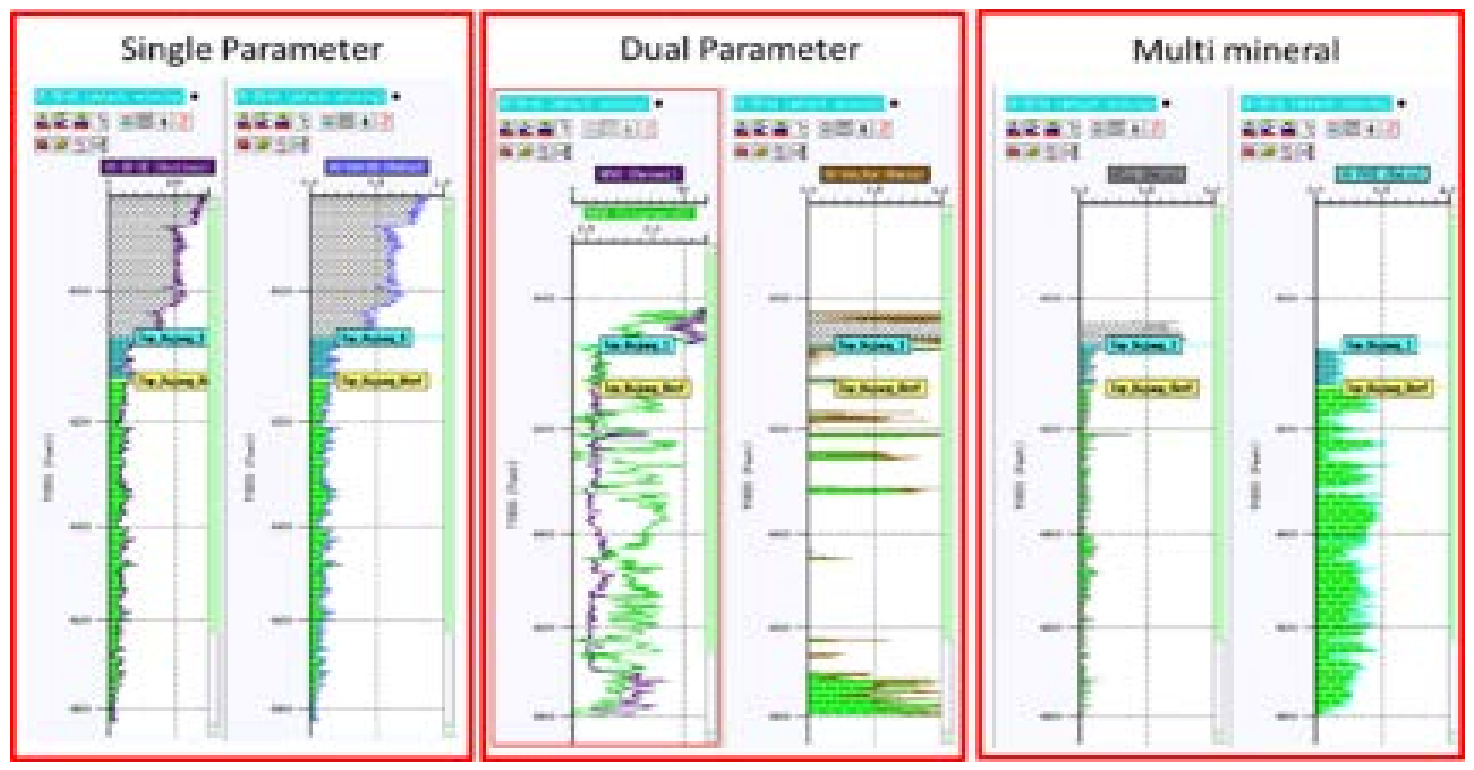

Gambar 8. Perhitungan vcl pada sumur U-A1 

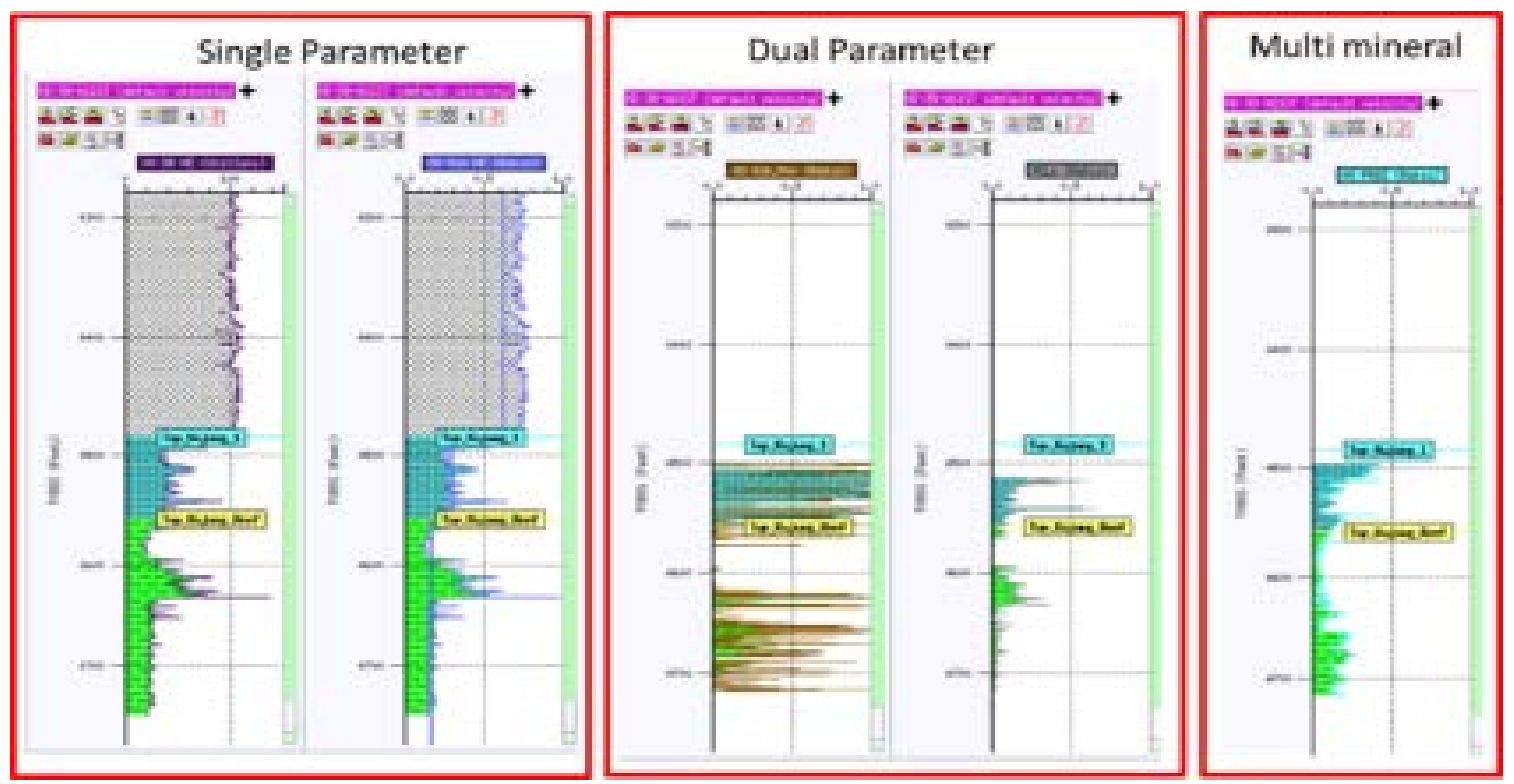

Gambar 9. Perhitungan vcl pada sumur U-A2.
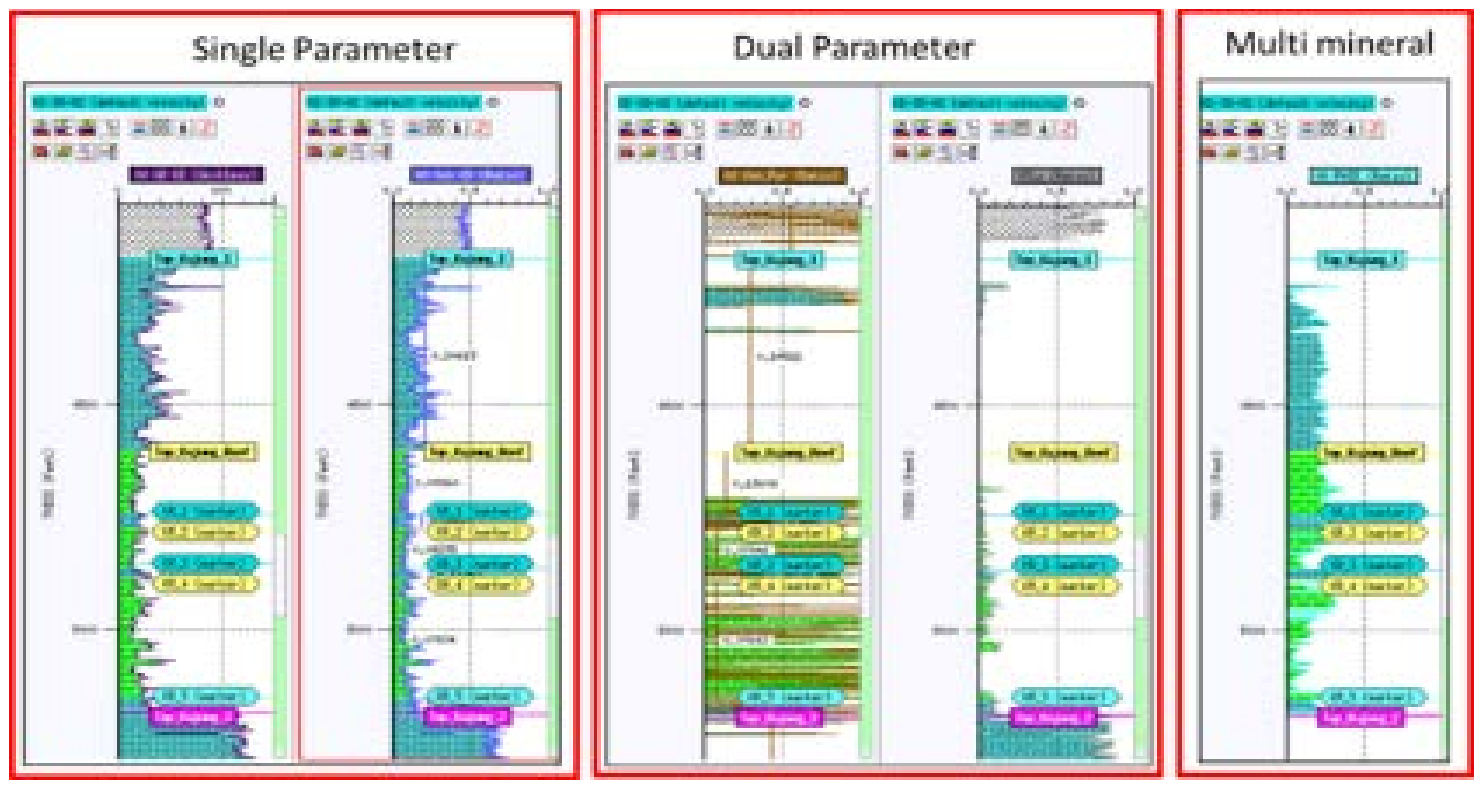

Gambar 10. Perhitungan vcl pada sumur U-A11st.

\subsubsection{Analisis Sekatan Sesar}

Hasil perhitungan daya sekat pada seluruh area penelitian diwakili oleh 3 sesar terkait keberadaan sumur di antara kedua sisi bidang sesar. 3 sesar tersebut mempunyai karakter yang berbeda yaitu:

> Sesar E-17 berada di area sebelah baratlaut area penelitian berupa sesar BULLETIN OF GEOLOGY, VOL. 2, NO. 1, 2018 DOI: 10.5614/bull.geol.2018.2.1.1 normal berarah baratdaya - timurlaut dengan kemiringan sesar $40^{\circ}-50^{\circ}$ ke arah baratlaut dan panjang sesar 16,4 km dengan kisaran throw mencapai $1200 \mathrm{ft}$ dengan beberapa synthetic sesar yang menempel (Gambar 11). Sesar ini merupakan pemisah antara JS-1 ridge 
(dominasi pinnacle) yang berada di bagian footwall, dengan Lapangan U-A (pinnacle dengan dominasi batugamping berlapis) pada bagian hangingwall. Potensi kebocoran HC pada formasi Kujung reef hanya dimungkinkan pada area di lingkaran merah (Peta Allan Gambar 11) karena pada area tersebut masih ada konektifitas antar reservoir dengan besar throw 20-200 ft. berdasarkan peta SGR yang sudah di filter pada reservoir-reservoir, dapat diinterpretasikan adanya kebocoran HC pada bidang sesar E-17 di area yang di lingkari yang dibuktikan dari asumsi arah migrasi HC yang berasal dari central deep telah mengalir melalui area tersebut. Nilai threshold berdasarkan pada area yang bocor mempunyai kisaran 0-16 (Gambar 12).

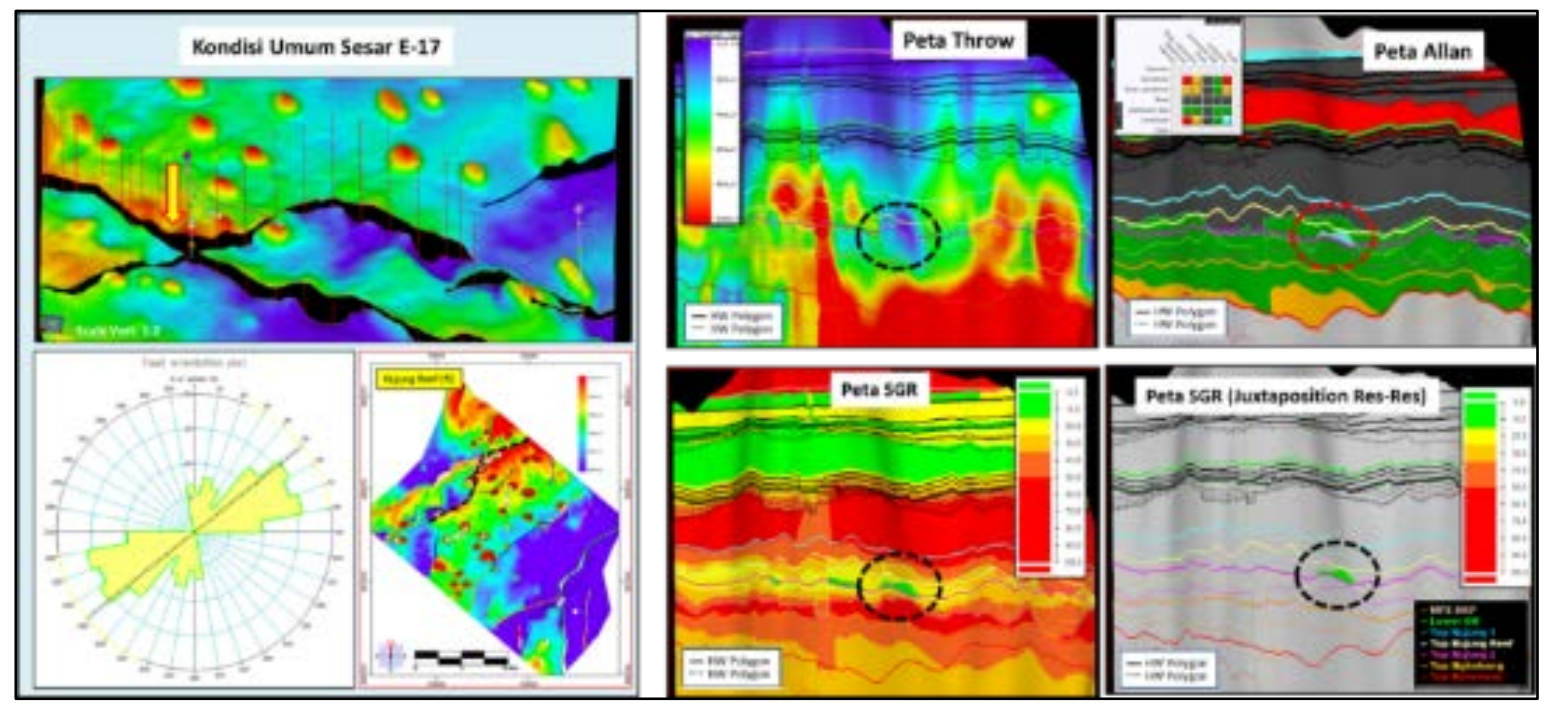

Gambar 11. Kondisi umur sesar dan hasil analisis sekatan pada sesar E-17.

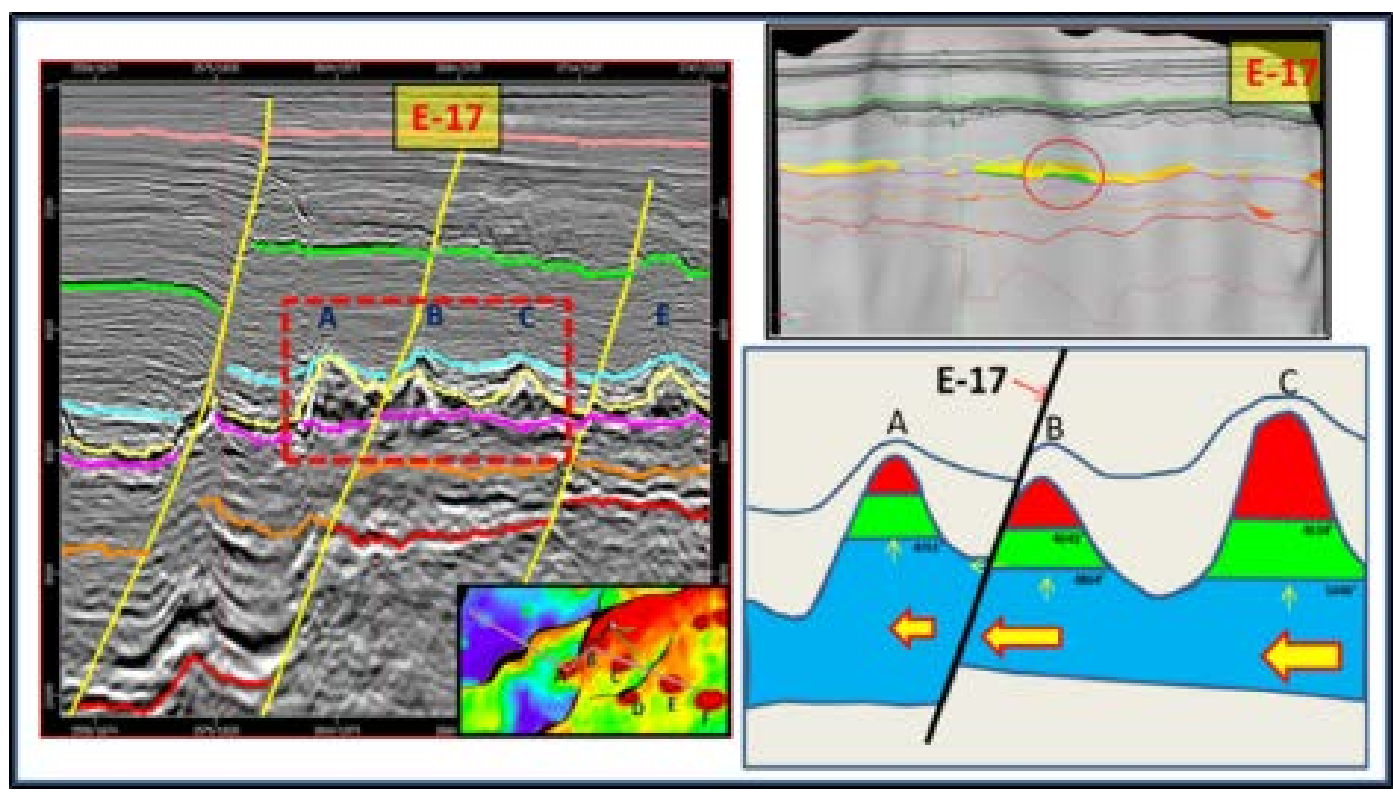

Gambar 12. Validasi analisis sekatan sesar E-17. 
Sesar E-3 berada pada bagian tengah JS-1 ridge dengan arah timurlaut - baratdaya dengan kemiringan sesar $40^{\circ}-50^{\circ}$ ke arah baratdaya dengan panjang sesar $16.4 \mathrm{~km}$ berupa sesar normal dengan besar throw hingga $600 \mathrm{ft}$ (Gambar 13). Sesar ini merupakan pemisah antara lapangan U-A dan Lapangan U-B dengan kondisi sesar menempel pada salah satu sisi barat pinnacle yang merupakan bagian dari lapangan U-B. Potensi kebocoran fluida terdapat pada area yang di beri lingkaran merah (Gambar 13) karena masih terdapat juxtaposition antara reservoir dengan nilai SGR antara 0-13. Berdasarkan keterdapatan hidrokarbon sesar tersebut bocor sehingga dapat di asumsikan bahwa sesar tersebut bocor melalui area yang diberi lingkaran merah (Gambar 14).
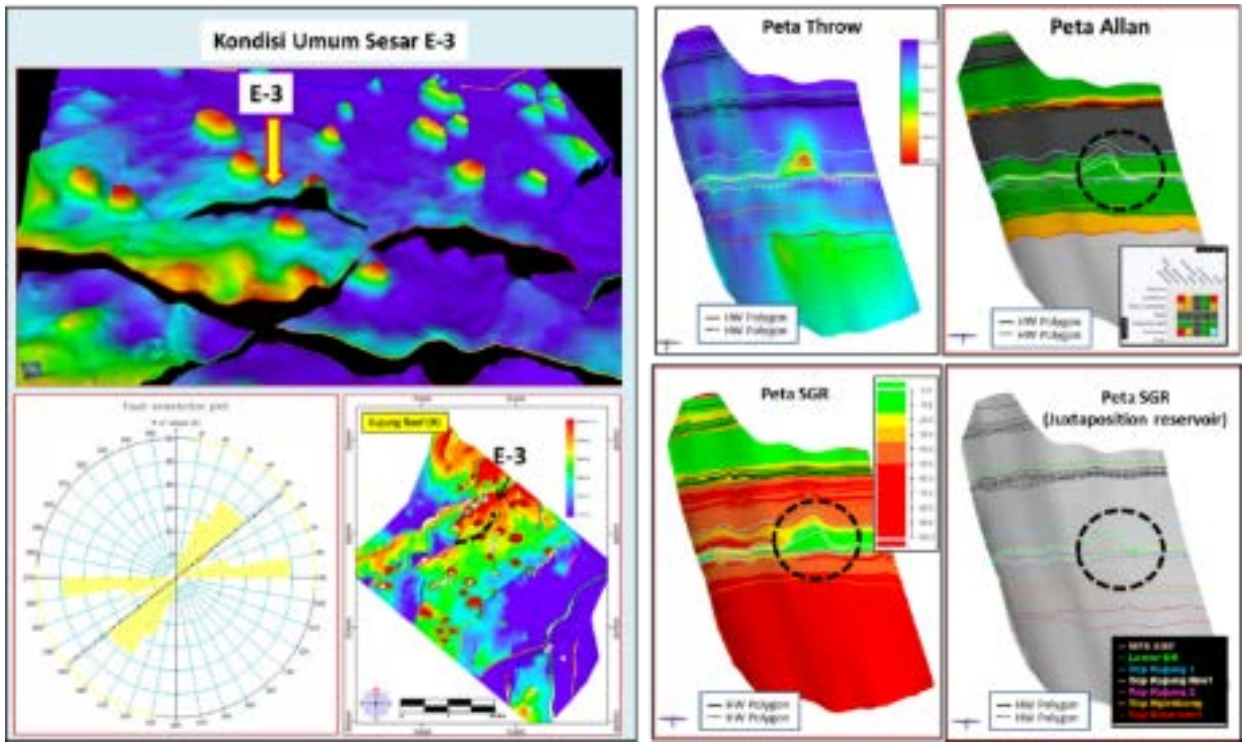

Gambar 13. Kondisi umur sesar dan hasil analisis pada sesar E-3.

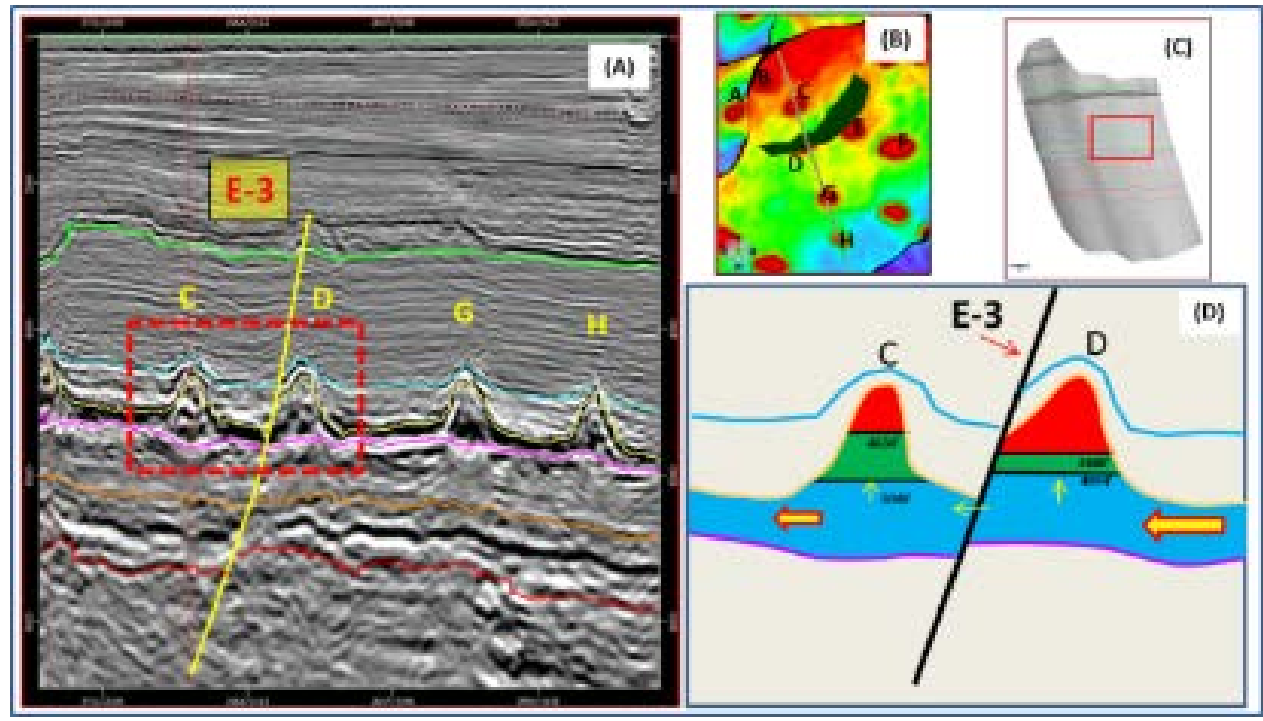

Gambar 14. Validasi analisis sekatan sesar E-3. 
Sesar E-11 berarah utara - selatan dengan kemiringan sesar $40-50^{\circ}$ ke arah timur dengan panjang sesar $19.4 \mathrm{~km}$ berupa sesar normal yang berada di bagian tenggara dari JS-1 ridge dengan lingkungan pengendapan pada pinggir slope sehingga perkembangan terumbu semakin habis yang terlihat pada lapangan S-A. Tetapi, pada bagian sisi barat sesar ini masih berkembang reef, hal ini dibuktikan oleh sumur di lapangan S-B (Gambar 15). Sesar ini merupakan sesar besar dengan pergerakan dari 100-2000 ft, sehingga juxtaposition antar reservoir hanya terdapat pada sedikit area yang telah di beri lingkaran merah. Area yang berpotensi mengalirkan fluida tersebut berdasarkan SGR mempunyai nilai di atas 35 sehingga berpotensi menjadi penyekat yang baik. Selain itu, berdasarkan keterdapatan Hidrokarbon pada kedua sisi sesar ini terlihat tidak adanya konektifitas, hal ini disebabkan hidrokarbon pada footwall (lapangan SB) berada pada kujung reef tetapi hidrokarbon pada hangingwall (lapangan S-A) terdapat pada reservoir Kujung 2. Kondisi Kujung 2 berupa batugamping platform yang terkekarkan dan berada pada level kedalaman yang jauh di bawah jika di sejajarkan Gambar 16).
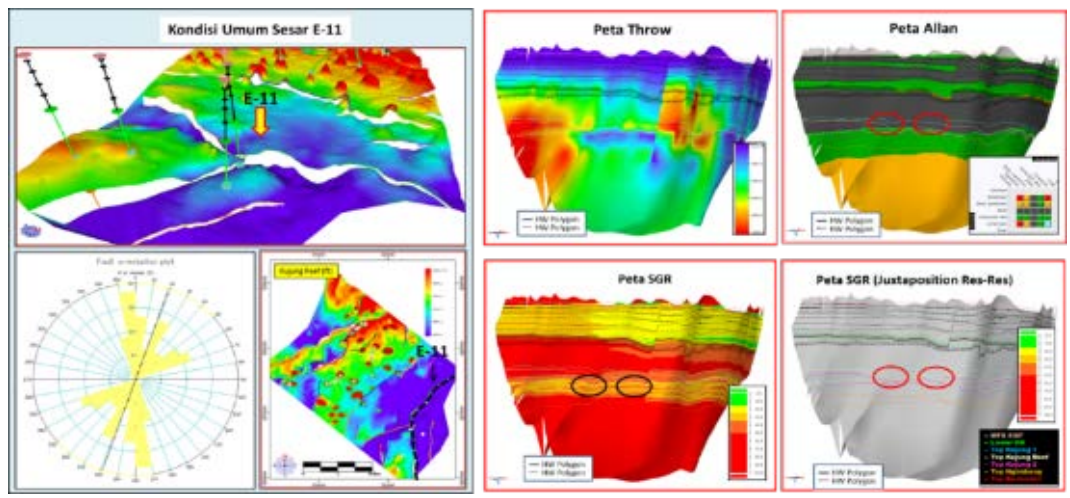

Gambar 15. Kondisi umur sesar dan hasil analisis pada sesar E-11.

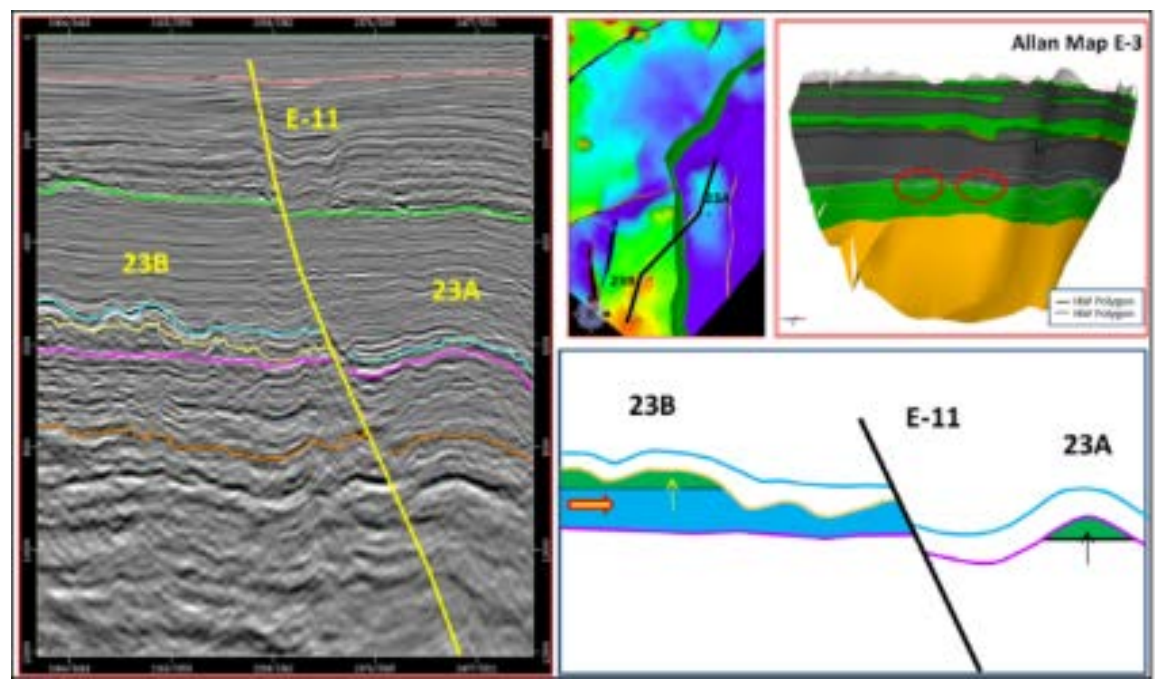

Gambar 16. Validasi analisis sekatan sesar E-11. 
Akumulasi hidrokarbon pada area penelitian terdapat pada reservoir kujung reef karena mempunyai porositas dan permeabilitas yang baik. Walaupun begitu, pada bagian pinggir JS-1 ridge terdapat juga akumulasi hidrokarbon pada lapisan di dibawahnya, berupa reservoir batugamping yang terkekarkan. berupa reservoir batugamping platform yang terkekarkan. Keberadaan sesar yang terdapat di bagian pinggir, tengah dan luar pada JS-1 ridge mempunyai karakteristik berbeda, berupa area dengan pinnacle Kujung Reef yang tidak terpengaruh oleh sesar. Hal ini menjadikan sesar bocor dan mengalir ke reservoir di bagian hangingwall nya. Pada sesar di bagian pinggir dan luar JS-1 ridge, akan lebih berpotensi menyekat walaupun adanya juxtaposition reservoir. Berdasarkan tiga sesar yang dianalisis dengan detail didapatkan nilai threshold SGR untuk reservoir kujung reef adalah: 0-16 leak, 1635 potensi leak dan seal, serta 35-100 seal. Berdasarkan data tersebut seluruh sesar pada area penelitian dilakukan analisis sekatan dan didapatkan kesimpulan:
Area baratlaut (Gambar 17 kanan bawah): sesar pada area ini berdasarkan nilai SGR relatif berwarna hijau yang mengindikasikan mempunyai nilai SGR berkisar $0-15$, sehingga pada area ini kemungkinan fluid pada reservoir akan mengalir melalui bidang sesar. Tetapi walaupun begitu secara struktur posisi Kujung Reef pada hangingwall akan lebih rendah sehingga untuk eksplorasi disarankan untuk mencari ke lapisan yang di atasnya dan juxtapose dengan per lapisan Kujung Reef.

Area tenggara (Gambar 17 kiri bawah): sesar pada area mempunyai nilai SGR diatas 25, sehingga pada area ini sesar lebih berfungsi sebagai penyekat yang disebabkan oleh throw pada area sebelah selatan besar dan perlapisan reservoir terumbu tidak begitu berkembang baik sehingga ketebalan dan properti nya kurang baik, tetapi walaupun begitu potensi akumulasi hidrokarbon dapat di eksplorasi pada reservoir yang lebih bawah karena lebih dekat dengan formasi penghasil minyak yaitu Formasi Ngimbang.

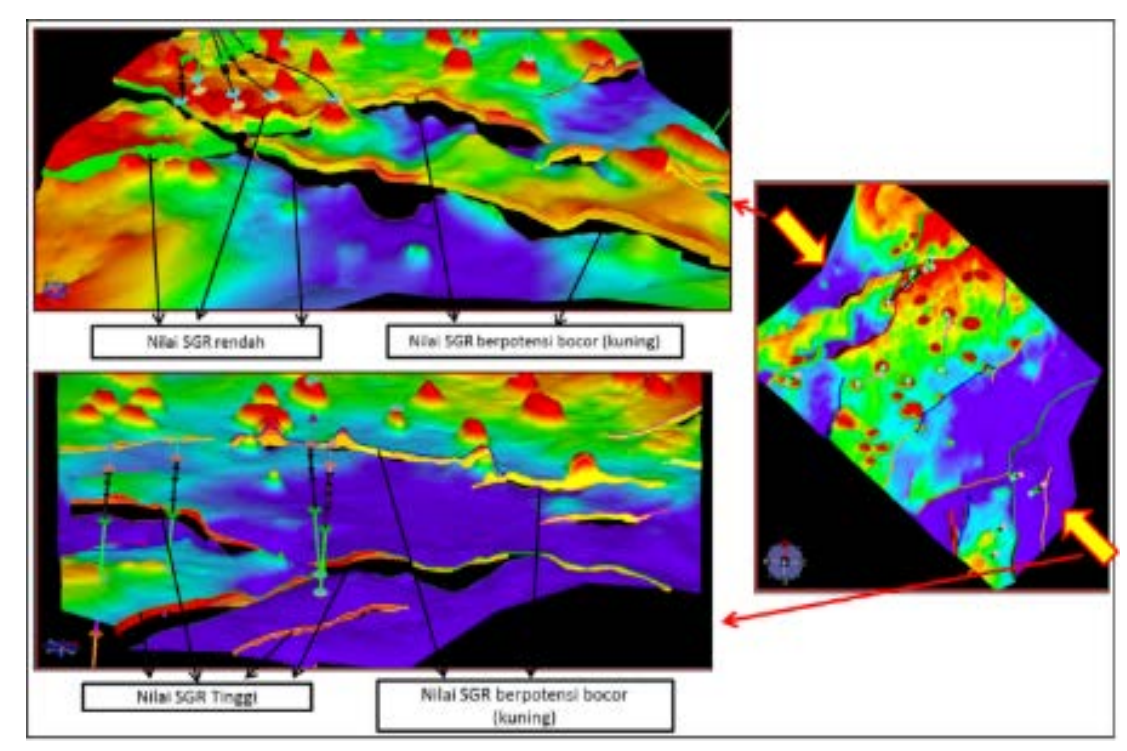

Gambar 17. Peta SGR dan SGR filter good reservoir "Kujung Reef'dan poor reservoir “Kujung I dengan nilai vsh rendah" pada bidang sesar E-17. 


\section{KESIMPULAN}

a) Area JS-1 ridge adalah area paparan stabil berupa horst dengan arah timurlaut - baratdaya dengan dua graben yaitu graben Bawean yang berada di sebelah baratlaut dan graben Central Deep di sebelah tenggara dengan penurunan yang dikontrol oleh sesar-sesar normal.

b) Formasi Kujung Reef merupakan member dari Formasi Kujung 1 berupa batugamping terumbu yang menyebar pada area JS-1 ridge. Formasi ini tidak berkembang ke arah graben di sebelah baratlaut dan tenggara, yang terbentuk berupa geometri build up dan menyebar sebagai pinnacle-pinnacle dengan properti porositas dan permeabilitas yang baik.

$>$ Perhitungan nilai volume shale pada batugamping pada objek penelitian dapat dihitung menggunakan metode single parameter dengan dasar log gamma ray setelah di koreksi terhadap hasil analisis multi-mineral, dengan besar ratio Formasi Kujung Reef antara 0-0.2.

$>$ Metode Shale Gouge Ratio (SGR) bisa diterapkan pada reservoir batugamping dengan beberapa kesimpulan:

o Pada batugamping terumbu dengan kandungan lempung yang sangat rendah akan berkorelasi dengan nilai vsh yang rendah sehingga gouge yang dihasilkan sekitar 0-16 dan berpotensi untuk tidak menjadi penyekat, hal ini terlihat pada sesar E-17 dan E-3 yang bocor pada area juxtaposition reservoir yang sama.

o Pada batugamping selain terumbu akan memiliki kandungan lempung yang lebih banyak sehingga akan berpotensi

BULLETIN OF GEOLOGY, VOL. 2, NO. 1, 2018 DOI: 10.5614/bull.geol.2018.2.1.1 menjadi penyekat jika tersesarkan, hal ini terbukti pada sesar E-11 dengan nilai SGR lebih dari 35 dengan kehadiran minyak yang gas pada zona yang berbeda pada kedua sisi sesar.

Daya sekat pada sesar di Formasi Kujung Reef dipengaruhi oleh besarnya kandungan shale/clay yang dipengaruhi oleh perubahan litologi dibandingkan oleh besarnya throw sesar. Sehingga, dengan dominasi karbonat terumbu, sesar akan lebih berpotensi mempunyai daya sekat yang rendah (leak). Pada dominasi karbonat platform, sesar akan membentuk gouge yang akan menjadi penyekat pada bidang sesar (seal).

> Threshold dari nilai SGR pada lapisan batugamping terumbu pada area penelitian mempunyai kisaran (Gambar V-1):

o 0-16 leak.

o 16-35: potensial leak or seal (tidak bisa disimpulkan pada penelitian ini).

o 35-100: seal.

c) Pengetahuan terkait analisis sekatan pada penelitian ini dapat mengetahui:

$>$ Jalur migrasi hidrokarbon dari Central Deep hingga ke struktur tempat akumulasi hidrokarbon.

> Potensi eksplorasi untuk mencari keberadaan minyak berupa:

i. Potensi pada reservoir di atas Formasi Kujung Reef pada area sebelah baratlaut JS-1 ridge.

ii. Potensi pada reservoir di bawah Formasi Kujung Reef pada area sebelah tenggara JS-1 ridge.

iii. Potensi struktur dengan struktur fault bounded pada area di sebelah timur JS-1 ridge. 


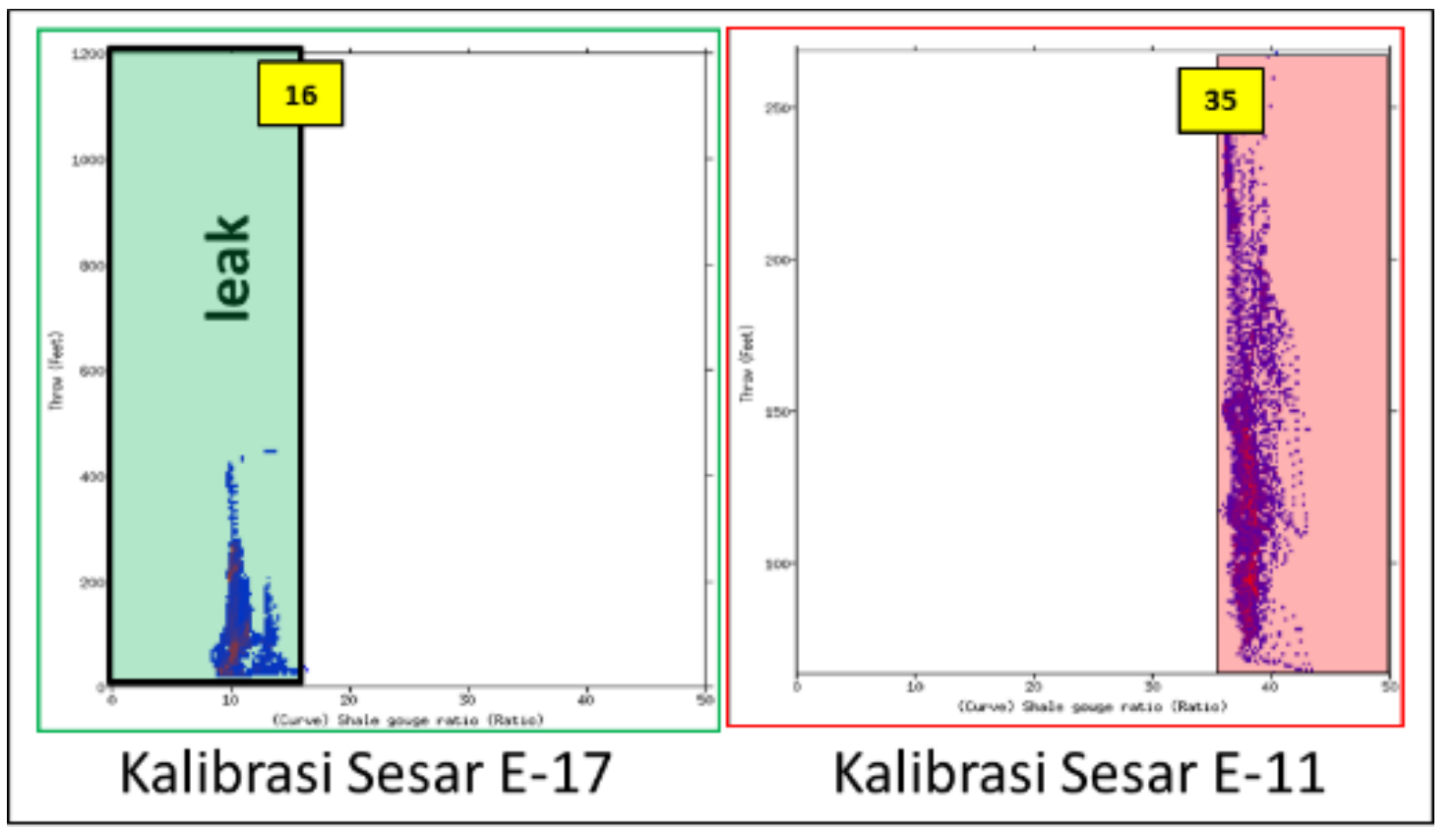

Gambar 18. Sebaran potensial sekatan berdasarkan Shale Gouge Ratio pada reservoir Kujung Reef di area penelitian.

d) Pengetahuan terkait analisis sekatan pada penelitian ini dapat mengetahui:

$>$ Jalur migrasi hidrokarbon dari Central Deep hingga ke struktur tempat akumulasi hidrokarbon.

$>$ Potensi eksplorasi untuk mencari keberadaan minyak berupa:

i. Potensi pada reservoir di atas Formasi Kujung Reef pada area sebelah baratlaut JS-1 ridge.

ii. Potensi pada reservoir di bawah Formasi Kujung Reef pada area sebelah tenggara JS-1 ridge.

iii. Potensi struktur dengan struktur fault bounded pada area di sebelah timur JS-1 ridge.

e) Jalur migrasi pada area JS-1 ridge mengalir dari selatan kemudian naik ke sebelah selatan dari JS-1 ridge dan kemudian mengalir mengikuti kemiringan ke arah utara hingga mengisi struktur-struktur di sebelah utara area penelitian (garis panah warna biru pada Gambar 19).
Sesar-sesar di bagian baratlaut tidak bisa berfungsi sebagai penyekat karena Kujung Reef yang tebal dengan vsh yang rendah, sehingga pada setiap juxtaposition reservoir to reservoir akan menjadi penghubung fluida.

$>$ Pengisian hidrokarbon di area JS-1 ridge akan sulit mempunyai kolom hidrokarbon hingga spill point karena hidrokarbon akan terus mengalir akibat ketebalan dan kualitas properti reservoir yang baik.

$>$ Sesar-sesar pada bagian tenggara berfungsi sebagai penyekat dikarenakan kualitas reservoir dengan kandungan vsh yang tinggi disertai besar throw yang besar di sebelah selatan.

Keberadaan hidrokarbon pada area sebelah tenggara dapat difokuskan pada struktur yang dibatasi batas sesar dan berada di antara area migrasi dari Central Deep. 


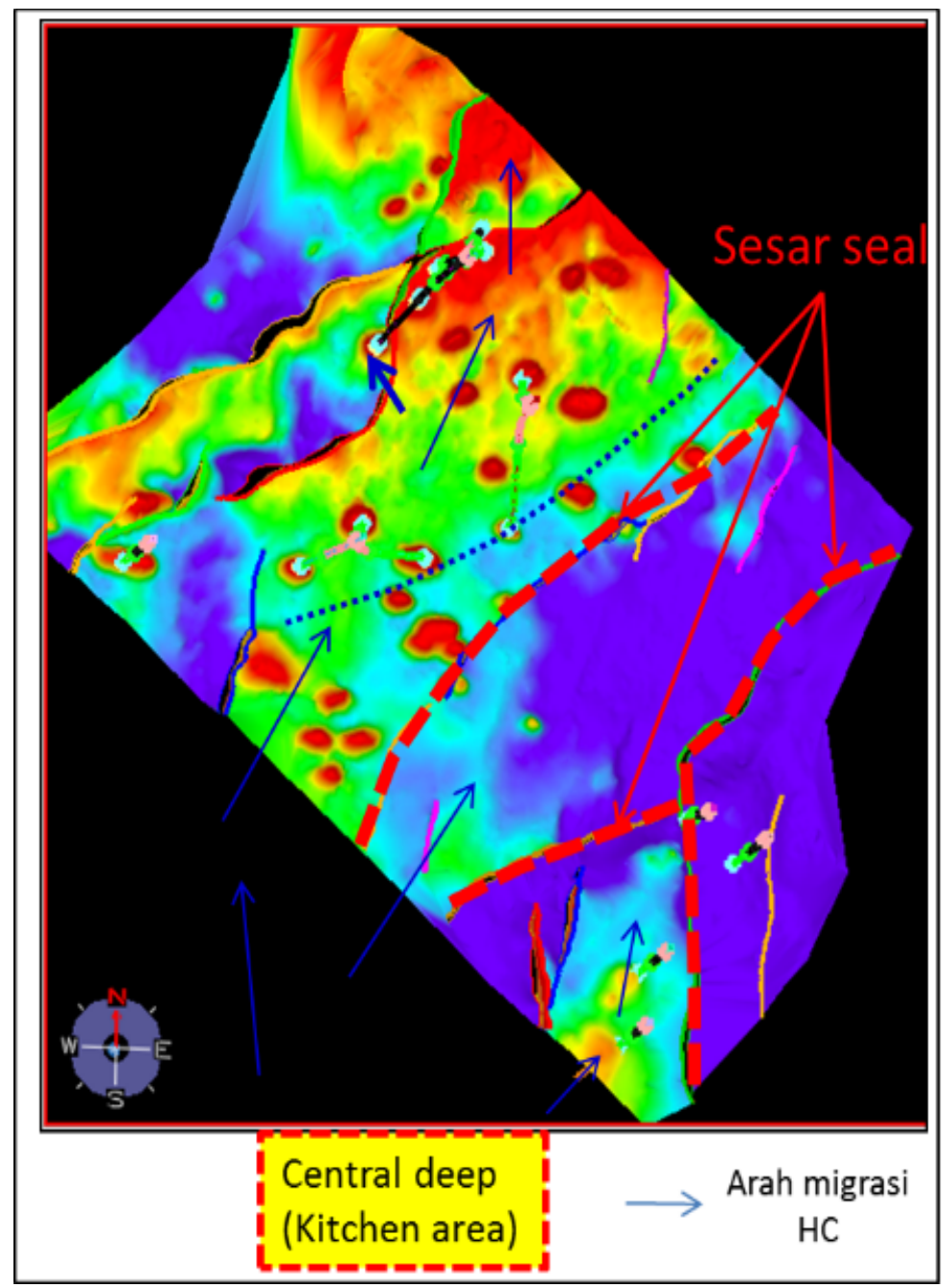

Gambar 19. Analisis sekatan sesar di Kujung Reef pada area penelitian.

\section{UCAPAN TERIMA KASIH}

Penulis mengucapkan terima kasih sebesarbesarnya kepada Benyamin Sapiie dan Indra Gunawan atas kerjasama dan masukan dalam penelitian ini. Terima kasih kepada jajaran management PT. Pertamina Hulu Energi West Madura Offshore (PHE-WMO) yang telah mengizinkan pemakaian data dalam penelitian ini.

\section{DAFTAR PUSTAKA}

BPMIGAS dan LAPI (2008): Portofolio eksplorasi hidrokarbon di KKKS Indonesia, tidak terbit.

Knipe, R J (1997): Juxtaposition and seal Diagrams to Help Analyze
Fault Seals in Hydrocarbon Reservoirs, Bulletin American Association of Petroleum Geologist, 2, 187-195.

KODECO (2010): Plan Of Development For Fields KE32, KE38, KE39 and KE54 and Gas Expansion Phase II in West Madura Offshore, Indonesia. Tidak terbit.

Mudjiono, R. dan Pireno, G.K (2002): Exploration of the North Madura Platform, Offshore, East Java, Indonesia, 28 ${ }^{\text {th }}$ Indonesian Petroleum Association, 707-722. 
Pertamina Hulu Energi West Madura Offshore (2015): laporan internal, tidak terbit.

Satyana, A.H (2005): Oligo-Miocene carbonates of java, Indonesia: Tectonic-Volcanic setting and Petroleum implication, $31^{\text {st }}$ Indonesian Petroleum Association, 217-249.

Satyana, A.H., Erwanto, E. dan Prasetyadi.C (2004): Rembang-MaduraKangean-Sakala (RMKS) Fault Zone, East Java Basin : The Origin and Nature of a Geologic Border, $33^{\text {rd }}$ Indonesian Petroleum Association.

Satyana, A.H. dan Purwaningsih, M.E.M (2003): Geochemistry of the east java basin: new observations oil grouping, genetic gas type and trends of hydrocarbon habitats, $29^{\text {th }}$ Indonesian Petroleum Association, 1-23.

Sapiie, B., Gunawan, I., Edward, E., Wibowo, R.A., dan Putra, P.R
(2015): Result of Using Different Petrophysical Approach in Controlling Fault. Seal Analysis in Rengasdengklok Area, Northwest Java Basin, Indonesia, $\quad 77^{\text {th }} \quad$ EAGE Confrence \& Exhibition 2015.

Smith, D. A (1980): Sealing and Nonsealing Faults in Louisiana Gulf Coast Salt Basin. AAPG Bulletin, 64, 145-172.

Trap Tester 5 Course (2004),Tidak di publikasikan.

Trap Tester Course (2014),Tidak di publikasikan.

Yielding, G., Bretan, P., dan Freeman, B (2010): Fault seal calibration: a brief review, Geological Society, London, Special Publications. 347, 243-255.

Yielding, G, Freeman, B., dan Needham, D.T (1997): Quantitative fault seal prediction, Bulletin American Association of Petroleum Geologist, 6, 89791. 